\title{
SUPERVISI KLINIS DENGAN TEKNIK DEMONSTRASI MENGAJAR UNTUK MENINGKATKAN KINERJA GURU
}

\author{
Firdaus \\ Pengawas Mapel Biologi SMA/SMK, Layanan Dikmen PK-PLK Bima, Dinas Pendidikan \\ dan Kebudayaan Propinsi Nusa Tenggara Barat \\ firdaus2205@yahoo.co.id
}

\begin{abstract}
ABSTRAK
Dalam rangka meningkatkan kualitas pendidikan, maka faktor kinerja guru menempati posisi yang sangat penting. Salah satu langkah strategis yang dapat dilakukan dalam upaya meningkatkan kinerja guru adalah melaksanakan teknik supervisi yang lebih efektif. Supervisi klinis sebagai salah satu model supervisi sangat diperlukan untuk membantu guru mengidentifikasi dan mengatasi segala kesulitannya terutama terkait dengan ketrampilan atau kemampuan mengajar. Dengan model supervisi klinis supervisor berusaha untuk mengubah perilaku mengajar guru agar menjadi lebih baik dengan cara yang efektif. Pada kenyataannya tindak lanjut dari suatu proses supervisi yang dilakukan pengawas hanya dilakukan melalui penjelasan secara verbal. Bagi guru yang memiliki komitmen dan kemampuan berpikir abstrak yang rendah, akan mengalami kesulitan dalam menterjemahkan arahan verbal tersebut. Oleh karena itu supervisor dalam melaksanakan supervisi memerlukan suatu teknik bantuan yang bisa dilihat secara langsung oleh guru dan dapat dicontoh. Oleh karena itu diperlukan model supervisi pembelajaran yang berbasis pada pengamatan demonstrasi mengajar guru lain yang lebih baik kemampuan mengajarnya (guru model). Oleh karena itu perlu dipadukan antara model supervisi klinis dengan teknik demonstrasi mengajar dalam proses supervisi, untuk menghasilkan proses supervisi yang lebih efektif memperbaiki kinerja guru dalam pembelajaran. Supervisi klinis dengan teknik demonstrasi mengajar dilaksanakan melalui tahapan-tahapan, yang merupakan gabungan dan irisan dari tahapan proses supervisi klinis dengan tahap proses demonstrasi mengajar. Berdasarkan proses penggabungan dari tahapan supervisi klinis dan tahapan demonstrasi mengajar, maka tahapan supervisi klinis dengan teknik demonstrasi mengajar terdiri dari (1) tahap penelitian dan observasi awal, (2) tahap pelaksanaan demonstrasi mengajar, (3) tahapan implementasi dan observasi mengajar, dan (4) tahap pertemuan balikan. Supervisi Klinis dengan Teknik Demonstrasi Mengajar memungkinkan keterbatasan jumlah pengawas sekolah tidak menjadi kendala dalam menjaga kualitas layanan supervisi, karena dilakukan dengan teknik berkelompok.
\end{abstract}

Kata kunci: Supervisi Klinis, Teknik Demonstrasi Mengajar, Kinerja Guru, Supervisi Klinis dengan Teknik Demonstrasi Mengajar. 


\section{PENDAHULUAN}

Supervisi klinis sangat diperlukan untuk membantu guru mengidentifikasi dan mengatasi segala kesulitannya terutama terkait dengan ketrampilan atau kemampuan mengajar. Sudjana (2012: 22) mengatakan bahwa supervisi klinis adalah proses tatap muka antara supervisor dengan guru untuk membicarakan berbagai hal tentang mengajar sebagai tugas pokoknya. Supervisi ini menekankan kepada bantuan individual kepada guru.

Supervisi klinis berkaitan erat dengan bagaimana membantu memperbaiki kemampuan mengajar guru berdasarka data hasil observasi yang kongkrit dan obyektif. Artinya dengan model supervisi klinis supervisor berusaha untuk mengubah perilaku mengajar guru yang masih kurang baik agar menjadi lebih baik dengan cara yang efektif. Menurut Asmani (2012: 107) bahwa salah satu karakteristik dari supervisi klinis adalah bahwa supervisor harus berfungsi sebagai subyek yang mengajarkan berbagai ketrampilan kepada guru atau calon guru, diantaranya adalah ketrampilan mengajar. Oleh karena itu berarti supervisi klinis berfokus pada perbaikan cara mengajar yang kongkrit.

Pada kenyataannya tindak lanjut dari suatu proses supervisi yang dilakukan pengawas untuk memperbaiki ketrampilan mengajar guru hanya dilakukan melalui penjelasan secara verbal saja mengenai hal-hal yang akan diperbaiki guru. Bagi guru yang memiliki komitmen dan kemampuan berpikir abstrak yang rendah serta minim pengalaman, akan mengalami kesulitan dalam menterjemahkan arahan verbal tersebut dalam mengimpelementasikan perbaikan kemampuan mengajar di kelasnya. Oleh karena itu supervisor dalam melaksanakan supervisi klinis memerlukan suatu teknik bantuan yang mengefektifkan proses supervisi dalam rangka meningkatkan kemampuan mengajar guru, yaitu teknik yang bisa dilihat secara langsung oleh guru dan dapat dicontoh.

Menurut Glickman (1981) dalam Makawimbang (2013: 43) bahwa dalam proses supervisi klinik perilaku seorang supervisor akan menentukan keberhasilan dalam membantu mengembangkan guru. Dengan berlandaskan pada pandangan psikologi belajar behavioristik, bahwa bagi guru yang masih rendah kemampuannya, maka pengawas menggunakan perilaku direktif untuk membimbing guru. Lebih lanjut menurut Glickman (1990) dalam Masaong (2013: 40) bahwa seorang supervisor yang berorientasi direktif harus menampilkan perilaku-perilaku pokok diantaranya adalah mendemonstrasikan (memodelkan) perilaku guru yang diinginkan dalam pembelajaran. 
Kegiatan pembelajaran guru adalah merupakan kinerja atau perilaku yang dapat diamati, oleh karena itu guru yang lemah kemampuan mengajar akan lebih baik jika mengamati langsung praktek pembelajaran dari orang yang lebih baik kemampuan mengajarnya untuk meningkatkan kemampuan mengajarnya, dibandingkan dengan hanya mendengarkan/dan memperhatikan penjelasan secara verbal. Hal ini sesuai dengan Teori Belajar Kognitif Sosial yang dikemukakan oleh Albert Bandura (dalam Arends, 2013: 4) bahwa banyak hal yang dipelajari manusia berasal dari pengamatan terhadap orang lain dan sebagian besar pembelajaran manusia dilakukan dengan mengamati secara selektif perilaku orang lain dan memasukkannya dalam memori. Menurut Bandura, bahwa pembelajaran melalui pengamatan merupakan proses tiga langkah: (1) pembelajar harus memperhatikan aspek-aspek penting dari apa yang akan dipelajari, (2) pembelajar harus mengingat perilaku tersebut, dan (3) pembelajar harus mampu memproduksi atau menampilkan perilaku tersebut (Arends, 2013: 5).

Dari penjelasan di atas maka Supervisi Klinis dengan Teknik Demonstrasi Mengajar menekankan kepada pemberian contoh yang kongkrit kepada guru melalui demonstrasi mengajar, dalam rangka mengefektifkan proses supervisi klinis dalam mengembangkan kemampuan mengajar guru. Dalam pelaksanaannya, supervisi klinis dengan teknik demonstrasi mengajar ini dapat dilakukan oleh pengawas, kepala sekolah, maupun guru yang diberi kewenangan oleh kepala sekolah. Supervisi ini selain dapat diterapkan dalam supervisi individual, juga dapat diterapkan dalam supervisi kelompok. Oleh karena dapat menjadi alternatif untuk membantu pengawas sekolah melaksanakan tugas kepengawasan terutama di wilayah yang jumlah pengawasnya terlalu sedikit sehingga tidak memungkinkan untuk menjangkau seluruh guru. Model Supervisi Klinis dengan Teknik Demonstrasi Mengajar memungkinkan keterbatasan jumlah pengawas sekolah tidak menjadi kendala dalam menjaga kualitas layanan supervisi.

\section{METODE PENELITIAN}

\section{KONSEP SUPERVISI KLINIS DENGAN TEKNIK DEMONSTRASI MENGAJAR}

Sergiovanni (1979) menyatakan bahwa supervisi pembelajaran dengan pendekatan klinik adalah suatu pertemuan tatap muka antara supervisor dengan guru, membahas tentang hal mengajar di dalam kelas guna perbaika pembelajaran dan pengembangan profesi (Imron, 2012: 59). Supervisi klinis adalah proses tatap muka antara supervisor dengan guru untuk membicarakan hal mengajar, dengan tujuan untuk membantu 
pengembangan profesional guru dan sekaligus untuk perbaikan proses mengajar itu sendiri, dan pembicaraan ini biasanya dipusatkan kepada penampilan mengajar guru berdasarkan hasil observasi (Aedi, 2014: 234).

Menurut Oliva (Sagala, 2012: 202) ada tiga aktivitas esensial dalam proses supervisi klinis, yaitu: (1) kontak dan komunikasi dengan guru untuk merencanakan observasi kelas, (2) observasi kelas, dan (3) tindak lanjut observasi kelas. Demikian juga Makawimbang (2013: 39) bahwa pelaksanaan supervisi klinis meliputi tiga langkah yaitu tahapan pertemuan awal, tahapan observasi mengajar, dan tahapan pertemuan balikan. Sebagai dasar untuk mengembangkan model supervisi klinis, penulias menggunakan tahapan supervisi klinis menurut konsep di atas.

Berbaikan dengan efektifitas supervisi klinis, beberapa hasil penelitian dapat dikemukakan di bawah ini. Menurut Okarji dan Ogbo (2013: 901-905) yang melakukan penelitian yang berjudul "Effects of Modified Clinical Supervision on Techer Instruction Performance". menunjukkan bahwa supervisi klinis yang dimodifikasi Cogan lebih efektif meningkatkan kinerja guru dibandingkan dengan pengawasan tradisional, mendorong kinerja guru dan murid yang lebuh besar, mempromosikan proses demokrasi, dan menciptakan hubungan partisipatif antara atasan dan guru. Selanjutnya penelitian Sihombing (2014) dengan judul "Meningkatkan Kinerja Guru Biologi SMA Negeri Dalam Pembelajaran Melalui Supervisi Klinis”, menunjukkan bahwa dengan membandingkan nilai hasil kinerja guru (dalam hal perencanaan pembelajaran, pelaksanaan pembelajaran, dan menilai hasil proses pembelajaran) dari pra siklus, siklus satu, dan siklus dua, maka peneliti menyimpulkan bahwa supervisi klinis dapat meningkatkan kinerja guru biologi dalam pembelajaran di SMA Negeri 1 Tukka dan SMA 1 Pinangsori Kabupaten Tapanuli Tengah.

Sementara itu demonstrasi mengajar merupakan salah satu teknik supervisi akademik secara berkelompok, walaupun ada juga ahli yang mengatakan bahwa demonstrasi mengajar merupakan teknik supervisi individual. Perbedaan ini sebenarnya terletak pada jumlah individu guru yang menjadi peserta dalam proses supervisi demonstrasi mengajar yang dilakukan oleh pengawas. Menurut Pidarta (2009: 183) bahwa teknik supervisi demonstrasi merupakan teknik supervisi kelompok, yaitu sejumlah guru disupervisi oleh seorang atau beberapa orang supervisi. Dalam tulisan ini supervisi demonstrasi mengajar yang dimaksud adalah merupakan perpaduan teknik supervisi individu dan kelompok. 
Secara sederhana proses demonstrasi mengajar dapat diartikan sebagai proses pelaksanaan pembelajaran yang dilakukan oleh seorang guru (baik dari pengawas, kepala sekolah atau guru yang ditunjuk) yang memiliki ketrampilan mengajar yang baik, yang dilakukan pada kelas yang sebenarnya untuk diobservasi oleh guru-guru lain, dengan tujuan agar guru-guru observer tersebut dapat mengembangkan ketrampilan mengajarnya pada saat kembali ke kelasnya masing-masing. Menurut Hariwung (1989: 172) demonstrasi mengajar adalah teknik supervisi yang diadakan oleh supervisor atau oleh guru-guru untuk memperagakan cara dan prosedur mengajar yang efektif, sehingga guruguru yang memiliki kelemahan-kelemahan mengajar dapat didorong dan ditolong untuk mengadakan perbaikan mengajar yang diadakannya sendiri di kelasnya.

Berdasarkan konsep supervisi klinis dan konsep demonstrasi mengajar di yang dijelaskan atas, maka supervisi klinis dengan teknik demonstrasi mengajar dapat diartikan sebagai proses membantu guru yang diawali dengan melakukan pertemuan antara supervisor dengan guru untuk membicarakan hal yang berkaitan dengan proses pembelajaran guru, bertujuan untuk perbaikan dan pengembangan kemampuan mengajar guru melalui proses mengamati kegiatan mengajar guru model, agar dapat mangambil contoh tentang perilaku mengajar, dalam rangka memperbaiki keterampilan mengajar di kelasnya sendiri.

Hal ini didasarkan pada prinsip teori belajar kognitif sosial yang dikemukakan oleh Albert Bandura (1977) dalam Arends (2013: 4) dikatakan bahwa:

Pembelajaran akan sangat melelahkan, kalau tidak ingin dikatakan tidak menentu, jika orang harus bersandar semata mata-mata pada efek tindakan mereka sendiri untuk memberitahu mereka apa yang harus dilakukan. Untungnya, banyak perilaku manusia dipelajari melalui pengamatan dengan pemberian contoh: dari mengamati orang lain seseorang membentuk gagasan tentang cara menampilkan perilaku baru, dan pada kesempatan sesudahnya informasi yang sudah dikodekan ini bertindak sebagai panduan tindakan.

Selanjutnya menurut Leeper (1969: 134) bahwa: “....the teaching demonstration is anexcellent device to illustrate specific teaching skills. It can focus attention up on only one skill by excluding other extraneous features of the classroom program”.

(Bahwa demonstrasi mengajar merupakan perangkat yang sangat baik untuk menggambarkan ketrampilan mengajar tertentu, sehingga dapat memusatkan perhatian terhadap suatu ketrampilan mengajar). Demikian juga Supardi (2014: 115-116) mengemukakan bahwa, demonstrasi pembelajaran adalah merupakan teknik supervisi yang 
dapat memberikan sumbangan besar bagi usaha peningkatan kemampuan pembelajaran guru-guru, karena dari mengamati demonstrasi pembelajaran dari supervisor atau guru model tersebut, guru dapat memperoleh berbagai pengetahuan tentang pembelajaran mulai dari cara memulai pelajaran, menggunakan metode pembelajaran, mendorong keikutsertaan peserta didik dan cara menyimpulkan hasil belajar itu sendiri dan bagaimana menutup kegiatan pembelajaran. Tahulending (2015) melakukan penelitian yang berjudul "Demonstrasi Cara Mengajar oleh Pengawas Sekolah Dapat Meningkatkan Kemampuan Guru Dalam Mengelola Proses Pembelajaran di Sekolah Binaan”. Dalam tulisan ini digambarkan adanya peningkatan kemampuan mengelola proses pengajaran pada guru binaan yang menjadi target, setelah dilakukan kegiatan demonstrasi cara mengajar suatu konsep yang langsung diamati oleh guru binaan yang bersangkutan. Berdasarkan hasil pengamatan, disimpulkan bahwa melalui kegiatan demonstrasi cara mengajar oleh pengawas sekolah bisa meningkatkan kemampuan mengelola proses pembelajaran pada guru binaan.

Menurut Leeper (1969: 134), bahwa proses pelaksanaan demonstrasi mengajar terdiri dari: (1) sesi pengarahan oleh supervisor dengan guru yang mendemonstrasikan pengajaran dan guru observer, (2) sesi pelaksanaan demonstrasi mengajar, (3) sesi pelaksanaan kegiatan diskusi setelah kegiatan demonstrasi, dan (4) sesi implementasi guru observer di kelasnya sendiri. Demikian juga menurut Bruce, dkk (2009:8) proses supervisi dengan teknik demonstrasi mengajar atau juga dengan istilah kunjungan ke kelas demonstrasi, meliputi proses sebagai berikutu: (1) tahap pra-konferensi; dimana guru observer bertemu dengan guru tuan rumah utuk membahas tentang tujuan observasi, perencanaan dan penilaian, keadaan siswa, dan isu-isu lain (2) tahap guru observer menghadiri demonstrasi pemebalajran, (3) tahap guru pengamat dan guru tuan rumah bertemu pasca-pembelajaran untuk membahas berbagai hal yang terkait pelaksanaan demonstrasi mengajar, dan (4) tahap guru mengimplementasikannya di kelas sekolah mereka.

Berdasarkan konsep tahapan proses supervisi klinis dan tahapan proses demonstrasi mengajar di atas, maka dapat dususun tahapan proses supervisi klinis dengan teknik demonstrasi mengajar yang merupakan penggabungan antara kedua proses tersebut, yang diawali dengan tahap observasi awal terhadap pembelajaran guru untuk mengetahui kemampuan awal guru dalam pelaksanaan pembelajaran, sebagai landasan yang kuat untuk mengetahui permasalahan yang dihadapi guru dalam pembelajaran. 


\section{KARAKTERISTIK SUPERVISI KLINIS DENGAN TEKNIK DEMONSTRASI MENGAJAR}

Karakteristik yang membedakan model supervisi klinis dengan teknik demonstrasi mengajar dengan supervisi yang ada saat ini, diantaranya adalah:

1. Supervisi klinis dengan teknik demonstrasi mengajar dilaksanakan setelah dilakukan observasi kunjungan kelas, dimana dari hasil supervisi tersebut supervisor dapat mengidentifikasi guru-guru yang memerlukan bantuan untuk meningkatkan kemampuan mengajar.

2. Inti dari pelaksanaan supervisi klinis dengan teknik demonstrasi mengajar adalah melibatkan secara aktif guru untuk mengamati atau mengobservasi secara langsung kegiatan pembelajaran guru model yang lebih baik kemampuan mengajarnya, untuk dijadikan sebagai contoh oleh guru pengamat.

3. Proses supervisi klinis dengan teknik demonstrasi mengajar dilakukan melalui tiga tahapan utama, yaitu tahap penelitian awal, tahap pelaksanaan dan tahap evaluasi.

4. Proses supervisi klinis dengan teknik demonstrasi mengajar memadukan antara teknik individual dan teknik kelompok. Pada tahap pertemuan penelitian awal dilakukan secara individual, pada tahap pelaksanaan dilakukan secara kelompok, dan pada tahap evaluasi dilakukan secara individual;

5. Pada pelaksanaan supervisi klinis dengan teknik demonstrasi mengajar peran supervisor tidak terlalu dominan, karena adanya keterlibatan guru model yang juga akan bertindak sebagai sumber informasi bagi guru-guru pengamat;

6. Pada saat penelitian awal supervisor lebih banyak menyimak secara seksama penuturan guru dan bertanya seperlunya untuk menggali akar permasalahan terkait dengan kelemahan guru dalam pengelolaan pembelajaran guru di kelasnya, sehingga guru tidak merasa sungkan untuk terbuka menceritakan berbagai permasalahan yang dialaminya kepada supervisor;

7. Fokus supervisi adalah ketrampilan mengajar guru yang dianggap sebagai permasalahan peroritas guru dalam pembelajaran di kelasnya;

8. Dapat dilaksanakan secara berkelanjutan setelah pelaksanaan seluruh rangkaian kegiatan supervisi klinis berbasis demonstrasi mengajar;

9. Pelaksanaan supervisi klinis dengan teknik demonstrasi mengajar dapat memanfaatkan forum Musyawarah Guru Mata Pelajaran (MGMP), karena beberapa tahapan supervisi dilakukan secara kelompok. 
Pengawas sekolah, kepala sekolah, maupun guru senior dapat bertindak sebagai supervisor dalam pelaksanaan supervisi klinis dengan teknik demonstrasi mengajar.

\section{KOMPONEN PELAKSANA SUPERVISI KLINIS DENGAN TEKNIK DEMONSTRASI MENGAJAR}

Supervisi klinis dengan teknik demonstrasi mengajar melibatkan komponenkomponen sebagai berikut:

\section{Supervisor}

Supervisor bisa berasal dari pengawas pendidikan, kepala sekolah atau guru yang diberikan tugas oleh kepala sekolah untuk melakukan supervisi. Tugas supervisor dalam pelaksanaan supervisi klinis dengan teknik demonstrasi mengajar ini antara lain:

a) Merencanakan kegiatan supervisi bersama dengan guru.

b) Melaksanakan proses supervisi klinis serta menjadi guru model dalam pelaksanaan demonstrasi mengajar jika memungkinkan;

c) Bersama guru, menunjuk guru model yang akan melaksanakan demonstrasi mengajar;

d) Mendampingi dan membimbing guru model dalam rangkaian pelaksanaan demonstrasi mengajar;

e) Menetapkan instrumen observasi bersama guru model dan guru pengamat;

f) Melaksanakan evaluasi hasil supervisi klinis dengan teknik demonstrasi mengajar kepada guru yang disupervisi, melalui proses observasi pembelajaran dan pertemuan balikan dengan guru yang disepervisi.

\section{Guru Model}

Guru model dalam kaitannya dengan pelaksanaan demonstrasi mengajar ini adalah seorang yang ditunjuk untuk melaksanakan kegiatan pembelajaran di dalam kelas yang sebenarnya, untuk diamati oleh guru lain yang lemah kemampuan mengajarnya agar guru pengamat tersebut dapat melakukan perbaikan mengajar yang diadakannya sendiri di kelasnya. Guru model tersebut bisa berasal dari guru senior, kepala sekolah atau pengawas yang memiliki kemampuan mengajar yang baik. Adapun tugas guru model dalam pelaksanaan supervisi klinis berbasis demonstrasi mengajar ini antara lain adalah: a) Mendiskusikan dengan supervisor tentang RPP yang akan dipakai pada saat pelaksanaan demonstrasi mengajar; 
b) Menyampaikan kepada forum pertemuan pra demonstrasi mengajar tentang rencana pelaksanaan pembelajaran yang telah disusun sebagai dasar pelaksanaan kegiatan pembelajaran pada saat demonstrasi mengajar;

c) Menjawab pertanyaan dari peserta pertemuan pra demonstrasi mengajar, terutama yang terkait RPP yang telah disusun;

d) Melaksanakan kegiatan demonstrasi pembelajaran sesuai dengan skenario pada RPP yang telah disepakati dengan supervisor dan guru observer;

e) Guru model menyampaikan hasil evaluasinya terhadap pelaksanaan pembelajaran yang telah dilakukannya pada saat pertemuan pasca demonstrasi mengajar;

f) Menjawab pertanyaan dari peserta pertemuan pasca demonstrasi mengajar jika ada, serta memberi saran kepada guru observer jika diminta.

3. Guru yang disupervisi (supervisee)

Hal-hal yang perlu dilakukan oleh guru yang diberi perlakukan supervisi klinis antara lain:

a) Menyampaikan secara terbuka segala permasalahan dan kendala-kendala yang dihadapi dalam pengelolaan pembelajaran di kelas;

b) Bersama dengan supervisor menetapkan kriteria keberhasilan tindakan pembelajaran untuk memperbaiki pembelajaran;

c) Menjawab pertanyaan yang diajukan oleh supervisor dengan sejelas-jelasnya;

d) Bersama dengan supervisor mencari solusi dan menetapkan bersama tindakan apa yang harus dikerjakan untuk mengatasi permasalahan pembelajaran;

e) Menyepakati bersama supervisor seluruh rangkaian proses supervisi klinis dan bersedia mengikutinya;

f) Bersama supervisor menyusun instrumen untuk mengukur kemampuan guru mengajar dan mengukur tingkat keberhasilan proses pembelajaran yang dialksanakan guru (dengan pedoman observasi);

g) Melaksanakan proses pembelajaran di kelas;

h) Berdiskusi dengan supervisor tentang hasil observasi

Mengadakan kesepakatan dengan supervisor untuk diadakannya kembali proses supervisi klinis dalam melihat perkembangan pengelolaan pembelajaran; 


\section{PROSEDUR SUPERVISI KLINIS DENGAN TEKNIK DEMONSTRASI MENGAJAR}

Supervisi klinis dengan teknik demonstrasi mengajar dilaksanakan melalui tahapantahapan, yang merupakan gabungan dan irisan dari tahapan proses supervisi klinis dengan tahap proses demonstrasi mengajar. Tahapan supervisi klinis yang dipakai dalam buku panduan ini terdiri dari tahap praobservasi, tahap observasi, dan tahap pertemuan balikan (pascaobservasi). Sedangkan tahapan demonstrasi mengajar terdiri dari pertemuan awal, pelaksanaan demonstrasi mengajar, pertemuan pasca demonstrasi, dan tahapan implementasi oleh guru di kelas.

Berdasarkan proses penggabungan dari tahapan supervisi klinis dan tahapan demonstrasi mengajar, maka tahapan model supervisi klinis dengan teknik demonstrasi mengajar terdiri dari (1) tahap penelitian dan observasi awal, (2) tahap pelaksanaan demonstrasi mengajar, (3) tahapan implementasi dan observasi mengajar, dan (4) tahap pertemuan balikan.

Adapun tahapan penelitian dan observasi awal bertujuan untuk mengetahui kebutuhan guru dalam rangka perbaikan dan pengembangan kemampuan mengajar guru yang didasarkan pada data hasil observasi yang real dan obyektif, serta hasil diskusi yang mendalam antara supervisor dengan guru, dan akan menjadi bahan utama untuk menganalisis kebutuhan guru. Pada tahap ini juga disepakati antara supervisor dengan guru mengenai konstrak supervisi, instrumen supervisi dan solusi untuk membatu memecahkan permasalahan guru dalam pembelajaran yaitu pengamatan demonstrasi mengajar.

Selanjutnya tahapan demonstrasi mengajar terdiri dari pertemuan prademonstrasi mengajar, pelaksanaan demonstrasi mengajar, dan pertemuan pascademonstrasi mengajar. Secara umum tahap ini bertujuan agar pelaksanaan demonstrasi mengajar berjalan dengan sukses, dan bermanfaat secara maksimal bagi guru-guru pengamat dalam mengembangan kemampuan mengajarnya.

Tahap implementasi dan observasi mengajar, adalah tahapan aplikasi dari guru terhadap hasil-hasil pengamatan demonstrasi mengajar guru model di kelasnya masingmasing. Kegiatan ini dilakukan observasi oleh supervisor untuk mengetahui ketercapaian guru sesuai konstrak yang disepakati. dilanjutkan dengan pertemuan balikan (pascaobservasi) untuk mengkomunikasikan secara demokratis dan obyektif terhadap pelaksanaan implementasi pembelajaran guru tersebut. 
Secara rinci tahapan pelaksanaan supervisi klinis dengan teknik demonstrasi mengajar akan dijelaskan masing-masing sebagai berikut:

1. Tahapan penelitian dan observasi awal; adapun kegiatan yang akan dilakukan pada tahap ini diantaranya adalah:

a) Supervisor bersama guru menyepakti pelaksanaan supervisi;

b) Supervisor melakukan observasi pembelajaran guru;

c) Bersama dengan guru supervisor menganalisis hasil observasi terhadap proses pembelajaran guru;

d) Guru menyadari memiliki kelemahan dalam beberapa aspek kemampuan mengajar, dan ingin memperbaikinya;

e) Supervisor bersama dengan guru menetapkan aspek kemampuan guru yang telah dicapai dan belum dicapai;

f) Supervisor meyakinkan guru bahwa melalui supervisi klinis berbasis demonstrasi mengajar guru dapat mengetahui kelemahnnya dan mampu memperbaiki dan mengambangkan kemampuan mengajarnya;

g) Dengan persetujuan guru, supervisor menetapkan guru tersebut untuk diikutkan pada tahap berikutnya

h) Supervisor bersama guru observer menetapkan fokus kemampuan mengajar yang akan diamati, dengan mengisi format pertemuan awal;

i) Supervisor bersama guru observer menetapkan instrumen observasi yang digunakan;

j) Supervisor bersama guru observer dan guru model menetapkan waktu pelaksanaan demonstrasi mengajar.

2. Tahapan pelaksanaan demonstrasi mengajar; adapun kegiatan yang akan dilakukan pada tahap ini diantaranya adalah:

a) Pada pertemuan prademonstrasi mengajar, supervisor bersama guru observer dan guru model melakukan review terhadap dokumen pembelajaran yang dipakai untuk demonstrasi mengajar.

b) Guru model, guru observer dan supervisor memasuki kelas secara bersama-sama, dan selanjutnya menempati posisi yang telah ditentukan.

c) Guru model melaksanakan/ mendemonstrasikan proses pembelajaran di dalam kelasnya sendiri dengan menggunakan RPP yang telah disepakati bersama;

d) Guru-guru observer dan supervisor melakukan observasi poses pembelajaran guru model dengan menggunakan instrumen observasi yang telah ditetapkan; 
e) Setelah selesai proses pembelajaran, guru model bersama-sama dengan guru observer dan supervisor keluar dari kelas dan langsung mengadakan pertemuan pascaobservasi yang bersifat informal untuk membahas secara bersama hasil observasi pembelajaran guru model;

f) Diakhir diskusi pasca observasi, bersama-sama membuat kesimpulan tentang hal-hal positif, hal yang perlu dikembangkan serta hal yang harus dihindari oleh para guru dalam kegiatan pembelajaran yang akan dilakukannya;

g) Mentapkan waktu untuk mengadakan tahapan implementasi dan observasi mengajar masing-masing guru observer pada kelasnya masing-masing.

3. Tahap implementasi dan observasi mengajar guru; adapun kegiatan yang akan dilakukan pada tahap ini diantaranya adalah:

a) Guru mengajar dan supervisor mengamati guru mengajar sesuai dengan kontrak yang disepakati bersama pada format pertemuan awal;

b) Supervisor mencatat dan dan merekam dengan cermat berbagai data dan informasi penting perihal guru mengajar sesuai kontrak yang disepakati.

c) Supervisor mengamati guru dengan cara menggunakan lembar observasi mengajar yang telah disepakati.

4. Tahap pertemuan balikan; adapun kegiatan yang akan dilakukan pada tahap ini diantaranya adalah:

a) Supervisor dan guru menciptakan suasana yang santai dan akrab dalam suasana keikhlasan dan objektif pada saat pertemuan pascaobservasi.

b) Dengan penuh antusias, kejujuran, dan keikhlasan supervisor menanyakan perasaan guru yang diobservasi secara keseluruhan.

c) Supervisor mengingatkan kembali kepada guru tentang kontrak tampilan mengenai ketrampilan yang disepakati untuk diamati.

d) Guru menjelaskan sendiri tentang ketrampilan mengajar yang sudah bisa dilaksanakan dengan baik dan yang belum bisa dilaksanakan dengan baik.

e) Guru menjelaskan sendiri kepada supervisor tentang penyebab belum tercapainya pelaksanaan ketrampilan mengajar tertentu dalam pembelajarannya.

f) Dengan suasana yang obyektif supervisor menunjukkan titik-titik lemah yang dilakukan guru dalam mengajar. 
g) Atas dasar masukan yang diberikan supervisor sebagai hasil pengamatan, supervisor menanyakan kembali perasaan guru dan memberikan waktu untuk menganalisis balikan.

h) Guru menyadari dan mengungkapkan akan kelemahan dan kelebihan yang ditampilkannya dalam pembelajaran.

i) Guru dan supervisor membangun kesepakatan bahwa akan dilakukan lagi kegiatan supervisi untuk memperbaiki ketrampilan mengajar guru.

Guru bersama supervisor mengisi format pertemuan akhir.

\section{HASIL DAN PEMBAHASAN \\ INDIKATOR KEBERHASILAN}

Pelaksanaan supervisi klinis dengan teknik demonstrasi mengajar dikatakan berhasil dengan indikator:

1. Meningkatnya kenarja guru dalam melaksanakan proses pembelajaran;

2. Terlaksananya proses supervisi klinis dengan teknik demonstrasi mengajar dengan baik, mulai dari tahap penelitian dan observasi awal, tahap demonstrasi mengajar, tahap implementasi dan observasi pembelajaran guru dan tahap pertemuan balikan;

3. Banyaknya guru yang ingin dilibatkan dalam proses supervisi klinis dengan teknik demonstrasi mengajar dalam rangka mengembangkan dan meningkatkan kemampuan mengajarnya;

4. Guru merasa nyaman dan percaya kepada supervisor, serta bersikap terbuka untuk mengungkapkan mengenai permasalahan yang dihadapinya dalam pengelolaan pembelajaran dan sebab-sebabnya.

\section{WAKTU PELAKSANAAN}

Waktu pelaksanaan tahapan yang ada pada model supervisi klinis dengan teknik demonstrasi mengajar adalah sebagai berikut:

1. Proses penelitian dan observasi awal dilakukan melalui serangkaian observasi pembelajaran guru yang dilakukan pada saat proses pembelajaran guru di kelasnya masing-masing, dan dilakukan secara individual;

2. Proses pelaksanaan demonstrasi mengajar dilakukan pada saat proses pembelajaran guru model di kelasnya. Sedangkan proses pertemuan prademonstrasi dan pascademonstrasi dilakukan secara informal, sebelum dan sesudah proses pembelajaran guru model, dan dilakukan secara kelompok. 
3. Proses implementasi dan observasi mengajar guru dilakukan melalui serangkaian observasi pembelajaran yang dilakukan pada saat proses pembelajaran guru di kelasnya masing-masing. Sedangkan pertemuan balikan dengan guru pasca observasi pembelajaran dilakukan sesaat sesudah pembelajaran berlangsung. Proses ini dilakukan melalui pertemuan individual antara supervisor dengan guru.

Dilihat dari sisi waktu yang digunakan, maka tahapan penelitian dan observasi awal, pelaksanaan demonstrasi mengajar, dan tahapan implementasi dan observasi mengajar guru, serta pertemuan balikan dalam pelaksanaan model supervisi klinis dengan teknik demonstrasi mengajar ini dilakukan dalam tiga tahapan waktu yang berbeda.

\section{KESIMPULAN}

Berkaitan dengan adanya supervisi klinis dengan teknik demonstrasi mengajar dan pelaksanaannya, maka dapat disusun beberapa kesimpulan:

1. Supervisi klinis dengan teknik demonstrasi mengajar disusun berdasarkan teori tentang kelebihan model supervisi klinis yang mengakomodasi kebutuhan guru serta bersifat kolegial dan demokratis dalam pelaksanaannya, dengan konsep belajar yang efektif tentang perilaku yang dapat diamati dengan mengamati perilaku orang lain, yang didasarkan pada teori belajar kognitif sosial dari Albert Bandura.

2. Pelaksanaan supervisi klinis dengan teknik demonstrasi mengajar dilaksanakan dalam suatu proses berbentuk siklus, yang terdiri dari empat tahap yaitu tahap penelitian dan observasi awal, tahap demonstrasi mengajar, tahap implementasi dan observasi mengajar guru, dan pertemuan balikan.

3. Guru model yang bertindak sebagai pelaksana demonstrasi proses pembelajaran yang akan di observasi oleh guru pengamat, merupaka orang yang memiliki kemampuan mengajar yang lebih baik. Guru model bisa berasal dari pengawas, kepala sekolah dan guru lain yang lebih senior yang mengampu mata pelajaran yang sama dengan guru-guru yang disupervisi.

Supervisor yang melaksanakan supervisi klinis dengan teknik demonstrasi mengajar dapat berasal dari pengawas, kepala sekolah, maupun guru lain yang ditunjuk oleh kepala sekolah. 


\section{DAFTAR PUSTAKA}

Aedi, Nur. 2014. Pengawasan Pendidikan: Tinjauan Teori dan Praktik. Jakarta: PT Rajagrafindo Persada.

Arends, Richard I. 2013. Belajar untuk Mengajar, Learning to Teach. Jakarta: Salemba Humanika.

Asmani, Jamal Ma'ruf. 2012. Tips Efektif Supervisi Pendidikan Sekolah. Jogjakarta: Diva Press.

Fathurrohman, Pupuh dan Suryana, AA. 2015. Supervisi Pendidikan Dalam Pengembangan Proses Pengajaran. Bandung: PT Refika Aditama.

Hariwung, A.J. 1989. Supervisi Pendidikan. Jakarta: Departemen Pendidikan Dan Kebudayaan, Direktorat Jenderal Pendidikan Tinggi, Proyek Pengembangan Lembaga Pendidikan Tenaga Kependidikan.

Imron, Ali. 2012. Supervisi Pembelajaran Tingkat Satuan Pendidikan. Cetakan kedua. Jakarta: Bumi Aksara.

Makawimbang, Jerry H..2013. Supervisi Klinis, Teori dan Pengukurannya. Bandung: CV ALVABETA.

Masaong, Abd. Kadim. 2013. Supervisi Pembelajaran dan Pengembangan Kapasitas Guru. Cetakan kedua. Bandung: CV Alfabeta.

Okorji, P.N., dan Ogbo, R.N. 2013. "Effects of Modified Clinical Supervision on Techer Instruction Performance”. Journal Of Emerging Trends in Educational Research and Policy Studies (JETERAPS), 4(6):901-905.

Pidarta, Made. 2009. Supervisi Pendidikan Kontekstual. Jakarta: PT RINEKA CIPTA.

Sihombing, Seven Sumihar. 2014. "Meningkatkan Kinerja Guru Biologi SMA Negeri Dalam Pembelajaran Melalui Supervisi Klinis". Jurnal Manajemen Pendidikan Indonesia, Vol. 6, No. 2 Oktober 2014: 77-96.

Sudjana, Nana. 2012. Supervisi Pendidikan, Konsep dan Aplikasinya Bagi Pengawas Sekolah (Seri Kepengawasan). Bekasi-Indonesia: Binamitra Publishing.

Supardi. 2014. Kinerja Guru. Cetakan kedua. Jakarta: PT Rajagrafindo Persada.

Tahulending, Pres A. 2015. "Demonstrasi Cara Mengajar Oleh Pengawas Sekolah Dapat Meningkatkan Kemampuan Guru Dalam Mengelola Proses Pembelajaran Di Sekolah Binaan”. J-TEQIP, Tahun VI, Nomor 1, Mei 2015: 32-41. 